International Journal of Current Microbiology and Applied Sciences ISSN: 2319-7706 Volume 8 Number 05 (2019)

\title{
Pistia Algae Grown in Canalization Grey Water Basins are the Valuable Object of Purifying of Sewage Waters (In the example of Andijan city, Uzbekistan)
}

\author{
Cholpona Kuchkarova*
}

Andijan Machine Building Institute, Tashkent, Uzbekistan

*Corresponding author

\section{Keywords \\ Biological purifying, Dyke, grey water, Water plant, Pictia, Irrigation \\ Article Info \\ Accepted: \\ 18 April 2019 \\ Available Online: \\ 10 May 2019}

\section{Introduction}

The regular observation or control of industrial and domestic grey water should be done according the list of programme sources of polluting natural environment. Nowadays the content of harmful elements in gutter and sewage grey water are increasing regularly. In its turn it brings to several serious problems.

Large scale development of different industrial branches, increasing number of urban objects for citizens, appearing new towns also increases demand pf pure drinking water. That's ways in the purpose of rational usage of drinking a lot of irrigational channels are built for field and problems of providing with pure drinking water the citizens are solving (P. sultonov).

Even though a lot of unique measures are taken in Uzbekistan for protecting the natural environment the most urgent problems of current day still stays building special equipment which will provide more effective ways of purifying canalization waters. It takes much time and effort the cleaning of sewage grey water from different harmful wastes. 
During the purifying grey water different methods are used. Such as: mechanical, physical, chemical and biological methods.

Any changes occurring in environment influences to natural conditions. The most important of all natural resources is water. The level of pollution and number of canalization grey water which flows into natural waters depends on kind of turfed and content of addings, stage of technological processes. Kind of substances polluting more than 150 thousand in duct water but only 250-300 of them can be neutralized or disposed by modern methods of detecting and neutralizing (Ergashev).

In cleaning of canalization grey water by biological methods often used method of enrichening duct water will green water plants (green algae). By using biological methods at about $80 \%$ of organic substances can nentralized.

Taking into account the climate conditions of Republic of Uzbekistan the level of cleaning duct water with biological methods using different water plants which have high structure can be increased for $90-99 \%$ (Shoyoqubov R.SH).

Except that the role of water is great in different industrial enterprises, in agriculture and domestic-sanitation branches. For example, only urban citizens of Andijan city sped at about 250 litres of water in a day and it will be $0.2 \mathrm{~km}^{3}$ of pure water in a year. In current days one of the priority was of cleaning of water is purifying by different biological methods and using them in irrigation of agricultural plants and their conditions are required by norms. For purifying duct water of manufacturing enterprises and domestic canalization waters in our research we use the water plant Pistiya stratiotes.
The scientist R. SH. Shoyakubov and his staff created biotechnological methods of cleaning grey from pig-breeding farms, poultry farms and flax reprocessing industry by means of a plant Pictia (1987). In this process the system, biology, morphology, anatomy of the plant Pictia and methods of its growing, usage in economy industry. The methods of biological purifying grey waters from industrial and domestic canalization in condition of Fergana valley, especially in Andijan district were not analyzed enough. That's why the scientific research on learning grey waters from manufactural plants of Andijan district is one of the urgent problems in protection of natural environment.

The main goal of scientific research to create the technology of growing algae plant Pictiya in domestic canalization grey waters of Andijan city and purify it from organic and mineral substances. By means of hydrobiont living on biological water plants, microorganisms and zooplantons in their living process produce special chemical substances which destroys pathogenic bacteria spreading different diseases in grey waters.

The great important role of deep and surficial plants on biological basins except microorganisms. At the result of photosynthetic acidity addition to enriching water with oxygen they also participate in dividing substance by filtering they adopt formed mineral substances and accelerate the process of purifying of grey water (Vinberg and others). The natural ways of spreading the water algae Pictia and systematic place.

Pictia refers to the family of water cabbage and street flowers (Pictia stratiotes) and is perennial plant, floating on the surface of water and forms water wine. Pictia is one of the ancient plants. Its remainings are found in the South of France and in North America (Angler, 1924). Current time it grows in Asia, 
Africa, Australia and Europe (Wolf, Malayeva 1966). The fruit of Pictia are dry in the form of unicellular capsule and it has several seeds. The crust of the capsule becomes thinner and gets light brown colour. At last the capsule breaks down when the seeds are ripen and go off. One part sinks in the bottom of the water basin and others attach the roots of the Pictiya. The full ripen seeds are brown colors but unripen one are green colour, seeds have long cylindrical shape and of a size of 1,5-2, 0 $\mathrm{mm}$. The weight of 1000 seeds is $2.2 \mathrm{gr}$. The calm period of Pictia seeds in introduction period as in natural conditions are very short. In favourable conditions (when the temperature of water is $25-26{ }^{0} \mathrm{C}$ and enough sunlight) the seeds after going out of capsule begin sprouting and growing. The critical factor in growing of Pictia has the light, as far as in dark place they will not grow even the temperature of the water is normal. The seeds of Pictya are persistent to long (till 60 days) cold temperature $\left(3-5{ }^{0} \mathrm{C}\right)$, begins growing in 14-16-days. In laboratory conditions (in aqua destillata, the temperature 26-28 and especially the light is needed) the sprouting of seeds consist 72\%. In botanic Parks the Pictiya is planted as decorative (Paramanova, 1961) and aquarium (Jdanov, 1973). However biomass of Pictia is used as a food for pig breeding (Wolf, 1969). Pistiya growing as a food for kattle the deeng of animals, grey water from domestic canalization and flax reprocessing industry, industry of producing mineral fertilizers, biochemical plants, silk producing industry, meat reprocessing plants city enterprises of social - domestic services (Shoyoqubov). According to the opinion of some scholars the growth only content of basic environment and kind of a water plant algae but also from the density of planted seeds of primary. The density of primary seed sprouts should be $1 \mathrm{~m}^{2}$ depending from food concentration of canalization grey water 1-3 kgr on the surface of $1 \mathrm{~m}^{2}$ grey water "in separate conditions $5 \mathrm{~kg} \backslash \mathrm{m}$ wet biomass. Pistya is grown efficiently on the grey water of pig breeding and poultry breeding farms. The harvest of biomass in such conditions for $1 \mathrm{~m}^{2}$ surface of grey water is 1400 grams of green wet biomass (Shoyaqubov, 1993-1997).

At the result of multi year scientific researches the most efficient methods of purifying of agricultural grey waters were worked out. They are Pictiastratotesz, Eyhoriya (Azolla Carolina wild) (photo-2).

Table.1 Crop yield of Pictiya on the canalization grey water of Andijan city

\begin{tabular}{|c|c|c|c|c|c|c|c|c|}
\hline \multirow[t]{4}{*}{ Experiment variants } & \multicolumn{6}{|c|}{ Biomass $\mathrm{g} / \mathrm{m}^{\mathrm{a}}$} & \multirow{3}{*}{\multicolumn{2}{|c|}{$\begin{array}{l}\text { The growth of massth } \\
\text { at the end of } \\
\text { experiment }\end{array}$}} \\
\hline & \multicolumn{3}{|c|}{ In three days } & \multicolumn{3}{|c|}{ At the end of research } & & \\
\hline & \multirow{2}{*}{$\begin{array}{c}\text { Wet bio } \\
\text { mass }\end{array}$} & \multicolumn{2}{|c|}{ Daily growth } & \multirow{2}{*}{$\begin{array}{c}\text { Wet bio } \\
\text { mass }\end{array}$} & \multicolumn{2}{|c|}{ Daily growth } & & \\
\hline & & $9 / \mathrm{m}^{2}$ & $\%$ & & $\mathrm{~g} / \mathrm{m}^{2}$ & $\%$ & $\mathrm{~g} / \mathrm{m}^{2}$ & $\%$ \\
\hline $100 \%$ grey water & 1045 & 15,0 & 101,5 & 2000 & 318,3 & 191,3 & 166,7 & 200 \\
\hline $\begin{array}{l}\text { Pictiya with canalization } \\
\text { grey water }+ \text { running water } \\
\text { from the tap }\end{array}$ & 1190 & 63,3 & 116,3 & 2595 & 468,3 & 218,0 & 265,8 & 259,5 \\
\hline $\begin{array}{c}\text { Pistiya with canalization } \\
\text { grey water + running water } \\
\text { from water tap } \\
(1: 3)\end{array}$ & 1225 & 75,0 & 107,5 & 2365 & 380,0 & 193,0 & 227,5 & 236,5 \\
\hline
\end{tabular}




\section{Photo.1 The photo of a plant Pictiya}

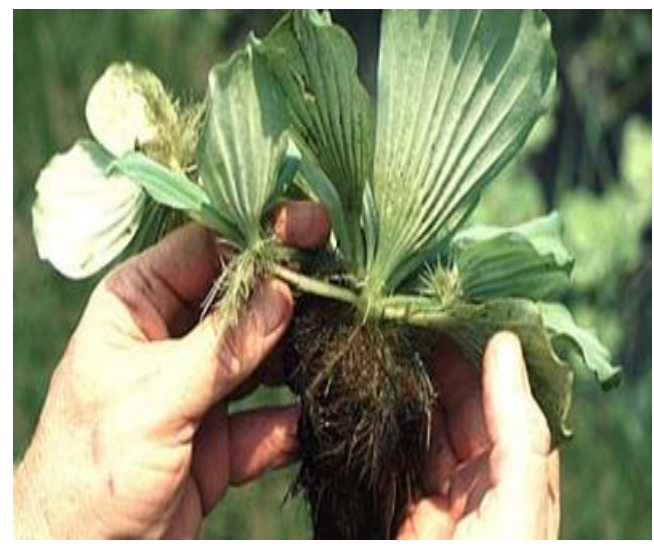

\section{Photo.2}

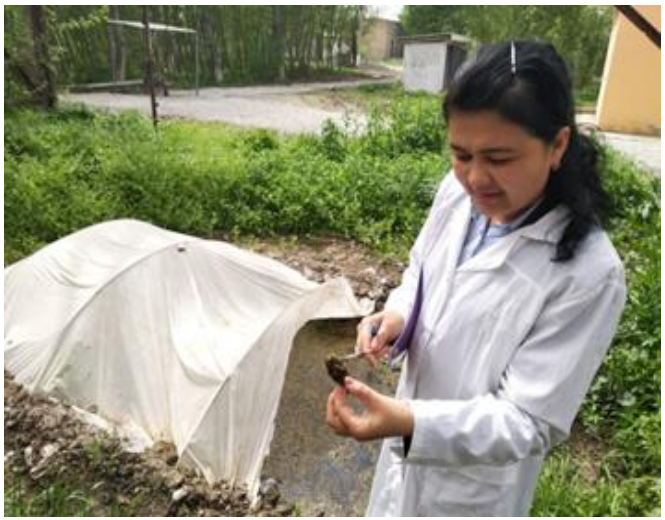

The growing and multiplication of process of algae Pictiya from seeds in laboratory conditions in the small water basins covered surface with plastic transparent material.

The goal of our current research is to use the water plant Pictiya for purifying the grey water in different concentrations $(25 \%, 50 \%$, $100 \%$ ) of liquid and experimenting its growths and crop yield. At the end of our experiments coming from its results we come to conclusion that the crop yield of the algae Pictiya was in $25 \%$ suitable habitat consists $237,5 \mathrm{gr} / \mathrm{m}^{2}$ in $50 \%$ grey, habitat $265,8 \mathrm{gr} / \mathrm{m}^{2}$ and in $100 \%-166,7 \mathrm{gr} / \mathrm{m}^{2}$ and the most suitable version is $50 \%$ (Table 1). It gives us confidence to say that Pictiya can be grown in grey domestic canalization waters of Andijan city and it gives the opportunity of purifying the grey waters. In its turn it will protect environment by saving microflora in open water basins.

\section{References}

Books: Zhdanov.AD. Cirilng, D., Aquarium and aquatic plants. St. Pemterburg, Gidromemoizdat. 1991. 186-1888 with

Book: Gillet. Watanabe. I. Microbiology of tropical soils and the rand of productivity / the hague: Nijhoff / Junk Publ. 1982. 169-185 p

Monographs: Muzaffrov, M.A. Flora of algae ponds of Central Asia. Tashkent. Science, 1965. $117 \mathrm{p}$.

Abstracts of dissertations: Shoyakubov. R.Sh. Biology of pististeleorisoid and the possibility of its practical use: Tashkent. 1993. 46 seconds Information about 
authors.

Articles published in collections: Eishman G.I., Litfak A.A. Water supply and wastewater treatment of chemical fiber enterprises. 1971. 154 Pp.

Manual: Ergashev A.E. Economic efficiency of the biological method of sewage treatment using algae. Tashkent. 1998. 123-124 p.

Shoyakubov R.SH. Sorceress Pistia Russia. Nature and Man, 1987. $55 \mathrm{p}$.

\section{How to cite this article:}

Cholpona Kuchkarova. 2019. Pistia Algae Grown in Canalization Grey Water Basins are the Valuable Object of Purifying of Sewage Waters (In the example of Andijan city, Uzbekistan). Int.J.Curr.Microbiol.App.Sci. 8(05): 2350-2354. doi: https://doi.org/10.20546/ijcmas.2019.805.277 